\title{
SMART FARMING TANAMAN SELADA (Romaine) DENGAN SISTEM AEROPONIK BERBASIS IOT
}

\author{
Galih Setiawan $^{a}$, M.Jasa Afroni ${ }^{b}$, Sugiono ${ }^{c}$ \\ a Teknik Elektro, Universitas Islam Malang, Kota Malang, Indonesia \\ ${ }^{b}$ Teknik Elektro, Universitas Islam Malang, Kota Malang, Indonesia \\ c Teknik Elektro, Universitas Islam Malang, Kota Malang, Indonesia \\ email:agalihsragi@gmail.com, bjasa.afroni@unisma.ac.id, cogionounismai@unisma.ac.id

\section{INFORMASI ARTIKEL}

Sejarah artikel:

Diterima : 23 juni 2021

Diterbitkan : juni 2021

Kata kunci: [Smart Farming Aeroponik] [Arduino Uno R3], [DHT11], [HC-SR04], [Internet Of Thing].

\begin{abstract}
Aeroponik adalah suatu media tanam dengan sistem pemberdayaan udara atau oksigen yang merupakan hasil modifikasi dari media tanam hidroponik dengan sistem pemberdayaan air. Aeroponik vertical farming merupakan sebuah inovasi baru dalam dunia pertanian yaitu desain media tanam aeroponik menggunakan box yang bersusun untuk mengatasi keterbatasan lahan, cara menggunakan media ini dengan menggantungkan akar tanaman yang disemprot air nutrisi melalui pompa air bertekanan tinggi dengan keluaran air berbentuk partikel yang dihasilkan sprayer. Pada sistem pengendali dan monitoring jarak jauh dipasang Arduino Uno R3 dan NodeMCU yang berisi program. Sensor DHT11 digunakan sebagai input pendeteksi keadaan suhu dan kelembaban di dalam greenhouse, sensor HC-SR04 ultrasonik digunakan untuk mendeteksi ketinggian air nutrisi di dalam box Aeroponik, hasil pembacaan sensor akan diterima oleh Arduino berbentuk nilai data yang kemudian dikirim ke relay untuk menyalakan dan mematikan selenoid valve, kipas DC, pompa air dan dapat dikendalikan oleh blynk yang terhubung dengan NodeMCU. Monitoring pembacaan sensor-sensor dan pengendali jarak jauh oleh Blynk dengan cara terhubung internet pada NodeMCU sebagai penerima dan pengirim data dari Arduino ke smartphone android pengguna.
\end{abstract}

\section{Pendahuluan}

Aeroponik berasal dari kata aero yang berarti udara dan ponus yang berarti daya. Aeroponik adalah memberdayakan udara atau bercocok tanam di udara. Sebenarnya aeroponik merupakan suatu tipe hidroponik (memberdayakan air) karena air yang berisi larutan hara disemburkan dalam bentuk kabut hingga mengenai akar tanaman. Pada aeroponik, akar tanaman dibiarkan tumbuh menggantung di udara dan akan menyerap larutan hara yang diberikan [1].

Selada merupakan salah satu sayuran yang banyak dibudidayakan dengan sistem aeroponik, variabel utama yang harus dikendalikan adalah suhu dan kelembaban udara di mana variabel tersebut merupakan faktor pendukung utama dalam cocok tanam aeroponik, selada dapat tumbuh pada suhu $25^{\circ} \mathrm{C}$ hingga $28^{\circ} \mathrm{C}$ dengan kelembaban $65 \%$ hingga $78 \%$ [3]. Pengendalian kelembaban udara serta suhu sesuai kebutuhan, membutuhkan rancangan metode dan alat yang dapat difungsikan sebagai pengendali tingkat kelembaban dan suhu udara. Sistem pengkondisian secara otomatis akan menjadi lebih mudah, efektif dan efisien jika dibandingkan dengan pengkondisian manual [3].

Penelitian ini mengusulkan alat Smart Farming Aeroponik dan greenhouse pengendali kelembaban dan suhu serta penyiraman berbasis loT untuk mengontrol pertumbuhan selada dengan menggunakan metode tanam Aeroponik Vertical Farming guna mendukung pertanian yang efisien.

\section{Penelitian Terdahulu}

Write some words of tile

(c) 2021 INFOTRON: Jurnal IImiah Teknik Informatika, Elektronika dan Kontrol (Scientific Journal of Informatics, Electronics and

Control Engineering). Copyrights. All rights reserved. 
Muhammad Widodo dkk, 2015, "Sistem Aeroponik Secara Otomatis Untuk Budidaya Beberapa Sayuran". Objek Penelitian yang digunakan ialah sayuran sawi dan kangkung. Rancangan aeroponik pada penelitian ini menggunakan mikrokontroler Arduino UNO Atmega 328. Sensor yang digunakan ialah sensor ultrasonik tipe PING sebagai pengendali level air nutrisi pada bak. Sensor DHT11 sebagai pendeteksi suhu dan kelembaban udara di sekitar tanaman. Timer dari module data logger shiled yang dilengkapi modul timer IC ds1307 digunakan sebagai module pewaktu sehingga data yang disimpan sesuai dengan kapan waktu pengambilan data yang disimpan.

Martha Vira Sariayu dkk, 2017. "Pengendali Suhu dan Kelembaban Pada Tanaman Selada (lactuca sativa I) dengan Sistem Aeroponik Berbasis Arduino UNO R3". Pada penelitian ini menggunakan Arduino UNO R3 yang berfungsi sebagai pengendali, penerima dan pengirim data keluaran sensor. Penggunaan sensor DHT11 berfungsi sebagai pendeteksi suhu dan kelembaban sekitar tanaman. Penambahan komponen driver motor L298N berfungsi sebagai driver motor DC dan stepper motor yang digunakan untuk pengendali pompa air DC dan kipas fan $12 \mathrm{~V}$ DC.

Alimuddin dkk, 2018, "Sistem Monitoring Parameter Suhu Cabe Merah dengan Sistem Aeroponik Pada Greenhouse Untuk Mendukung Ketahanan Pangan Nasional". Pada rancangan ini mengusung mikrokontroler Arduino Mega 2560 dan menggunakan sensor suhu DHT11 yang digunakan untuk memonitoring suhu dan kelembaban sekitar tanaman cabe merah.

Perbedaan antara penelitian terdahulu dengan skripsi ini adalah terletak pada desain sistem tanaman selada romaine Aeroponik berbasis IOT dengan metode Vertical Farming.

\section{Metode}

Rancangan sistem pengendali dan monitoring suhu kelembaban dan ketinggian air aeroponik jarak jauh berbasis internet of things dapat digambarkan pada blok diagram sebagai berikut:

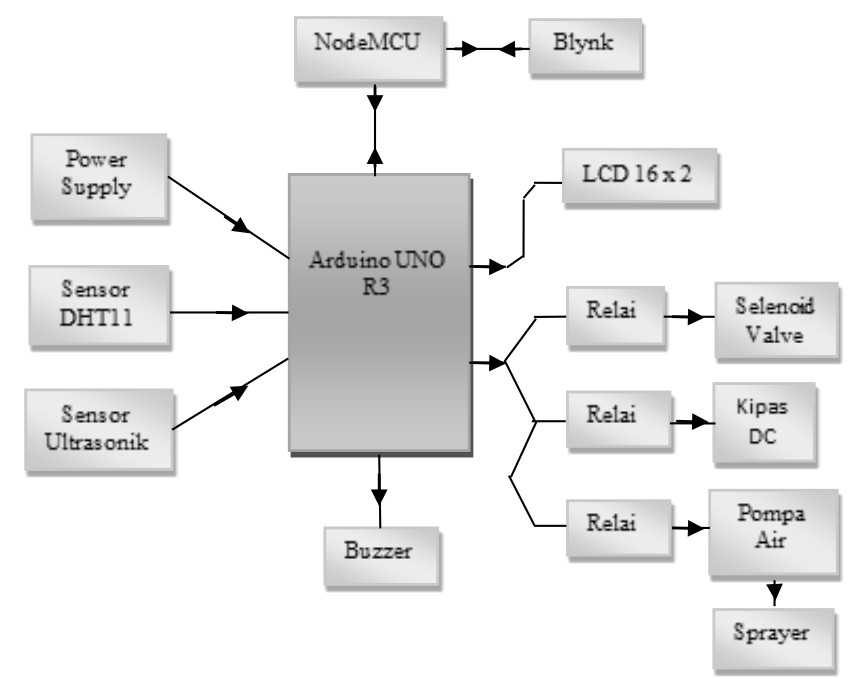

Gambar 1. Blok Diagram Smart Farming 


\section{Diagram Alir Sistem Smart Farming}
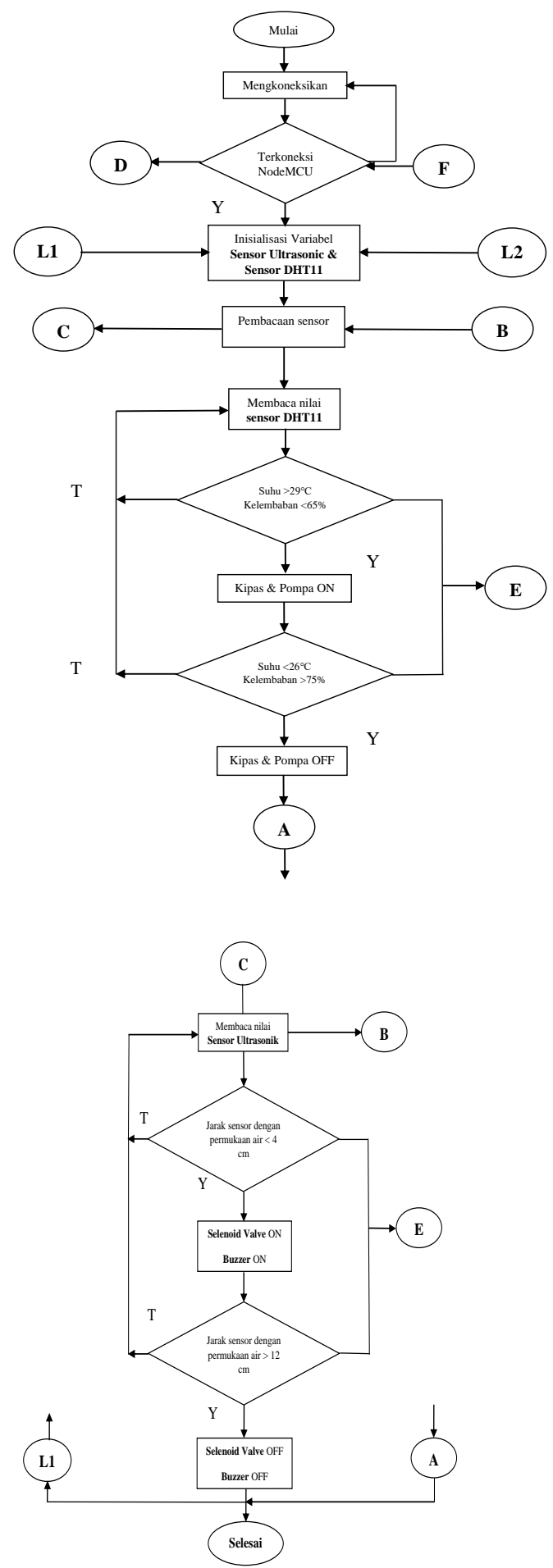


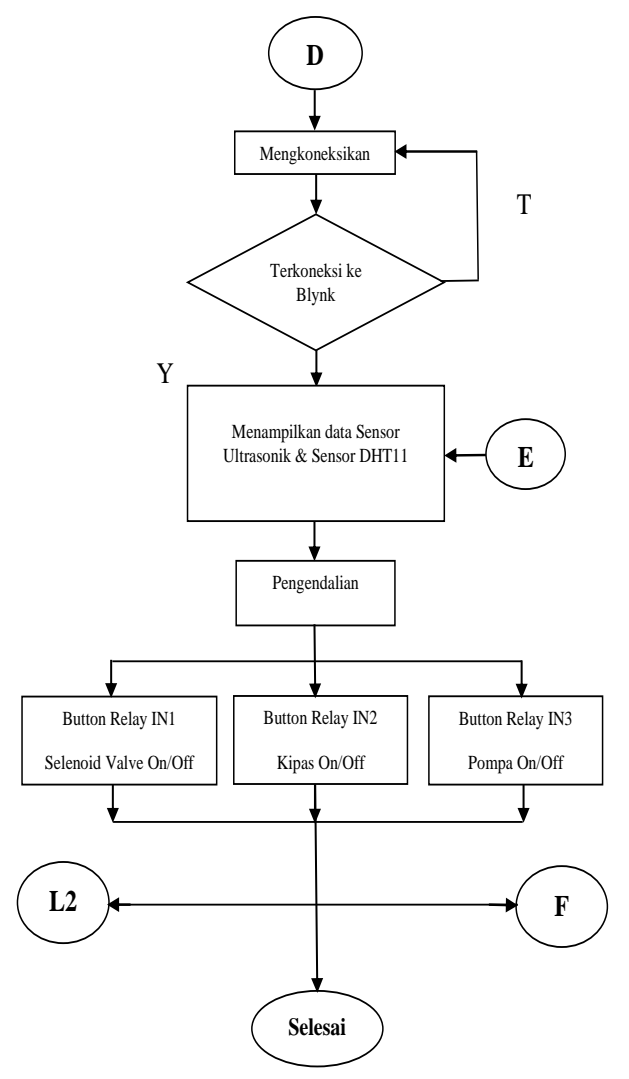

Gambar 2. Diagram Alir Sistem Smart Farming

Pada gambar di atas ialah diagram alir sistem dari sensor suhu dan kelembaban DHT11 dan sensor ultrasonik HC-SR04 dengan menggunakan sistem loop. Setelah selesai inisialisasi variable maka data nilai pembacaan sensor akan terbaca oleh Arduino Uno dan NodeMCU.

Range nilai pengendali ketinggian air nutrisi yang dideteksi oleh sensor Ultrasonik pada box aeroponik sebesar $4 \mathrm{~cm}-12 \mathrm{~cm}$ karena menyesuaikan ketinggian pipa keluaran sprayer didalam box $15 \mathrm{~cm}$, jika melebihi ketinggian pipa penyalur maka sprayer tergenang air nutrisi.

Range pengendali suhu dan kelembaban oleh sensor $\mathrm{DHT} 11$ suhu sebesar $26^{\circ} \mathrm{C}-29^{\circ} \mathrm{C}$ dan range kelembaban sebesar $65 \%-75 \%$, nilai range tersebut diprogram mengikuti nilai suhu dan kelembaban normal pada tempat penelitian.

\section{Desain Rancangan Aeroponik Vertical Farming}

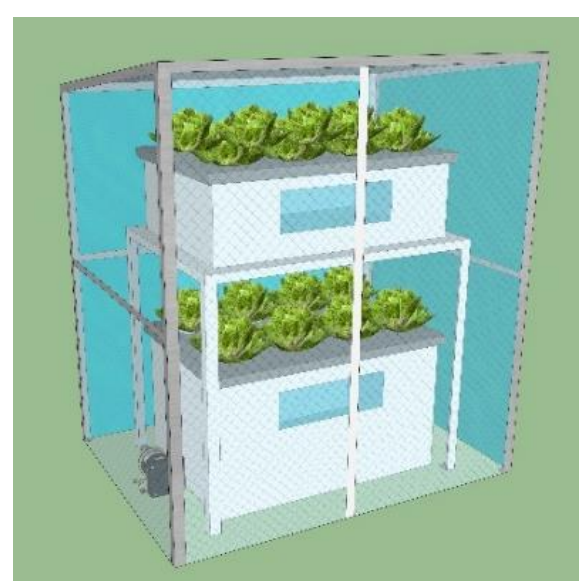

Gambar 3. Desain Aeroponik Vertical Farming

Write some words of tile ...

(c) 2021 INFOTRON: Jurnal IImiah Teknik Informatika, Elektronika dan Kontrol (Scientific Journal of Informatics, Electronics and

Control Engineering). Copyrights. All rights reserved. 
Media tanam Aeroponik diletakkan di dalam greenhouse dengan tutup plastik UV berfungsi untuk menghindari cuaca panas matahari berlebih, cuaca buruk dan serangan hama. Box mikrokontroler diletakkan disebelah ujung kiri atas greenhouse untuk sistem pengendali dan monitoring jarak jauh, sedangkan seluruh komponen lainnya dipasang didalamnya.

\section{Rangkaian Smart Farming Aeroponik}

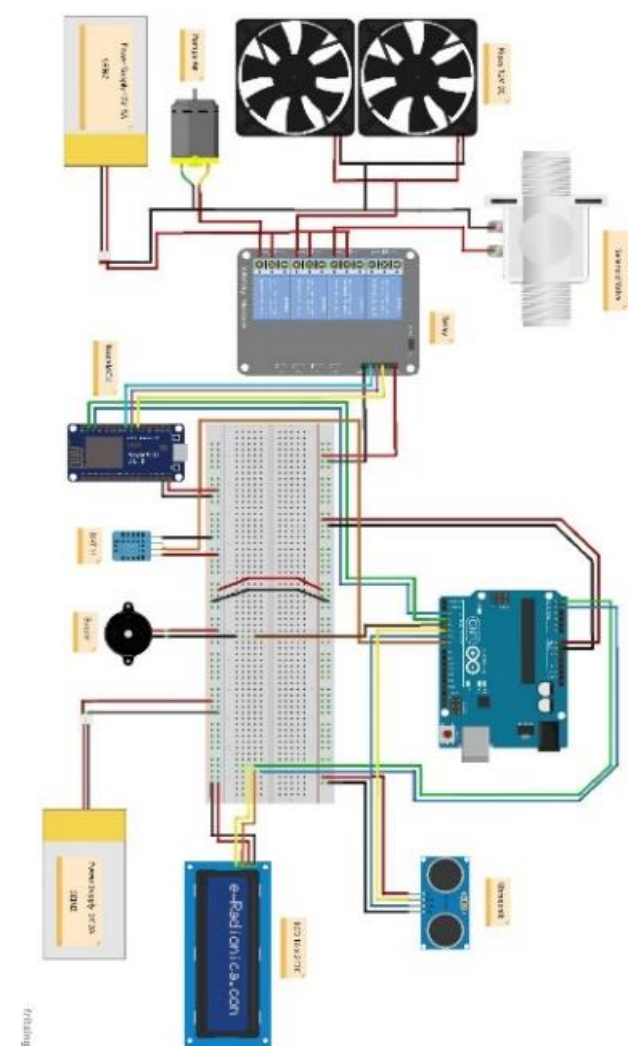

Gambar 4. Rangkaian Keseluruhan

Tabel 1, Perancangan Pin Arduino Uno R3

\begin{tabular}{|l|l|}
\hline Port Arduino & \multicolumn{1}{|c|}{ Koneksi Kabel } \\
\hline Pin VIN & $\begin{array}{l}\text { Pin +5V Power } \\
\text { Supply (jumper) } \\
\text { Pin -5V Power } \\
\text { Supply (jumper) }\end{array}$ \\
\hline Pin GND & Pin D2 NodeMCU \\
\hline Pin Digital 2 & Pin D1 NodeMCU \\
\hline Pin Digital 3 & Pin + Buzzer \\
\hline Pin Digital 4 & $\begin{array}{l}\text { Pin Trigger sensor } \\
\text { ultrasonik }\end{array}$ \\
\hline Pin Digital 5 & $\begin{array}{l}\text { Pin Echo sensor } \\
\text { ultrasonik }\end{array}$ \\
\hline Pin Digital 6 6 & $\begin{array}{l}\text { Pin Data sensor } \\
\text { DHT11 }\end{array}$ \\
\hline Pin Digital 7 7 I C \\
\hline Pin Analog A4 & Pin SDA LCD I2C \\
\hline Pin Analog A5 & Pin SCL LCD I2C \\
\hline
\end{tabular}

Tabel 2, Perancangan Pin NodeMCU

\begin{tabular}{|l|l|}
\hline Pin NodeMCU & \multicolumn{1}{|c|}{ Koneksi Kabel } \\
\hline Pin VIN & $\begin{array}{l}\text { Pin }+5 V \text { Power } \\
\text { Supply (jumper) }\end{array}$ \\
\hline Pin GND & $\begin{array}{l}\text { Pin }-5 V \text { Power } \\
\text { Supply (jumper) }\end{array}$ \\
\hline
\end{tabular}




\begin{tabular}{|l|l|}
\hline Pin D1 & $\begin{array}{l}\text { Pin Digital 3 } \\
\text { Arduino }\end{array}$ \\
\hline Pin D2 & $\begin{array}{l}\text { Pin Digital 2 } \\
\text { Arduino }\end{array}$ \\
\hline Pin D5 & Pin IN1 Relay \\
\hline Pin D6 & Pin IN2 Relay \\
\hline Pin D7 & Pin IN3 Relay \\
\hline
\end{tabular}

\section{Hasil and Pembahasan}

\section{Diagram Alir Perancangan Sistem}

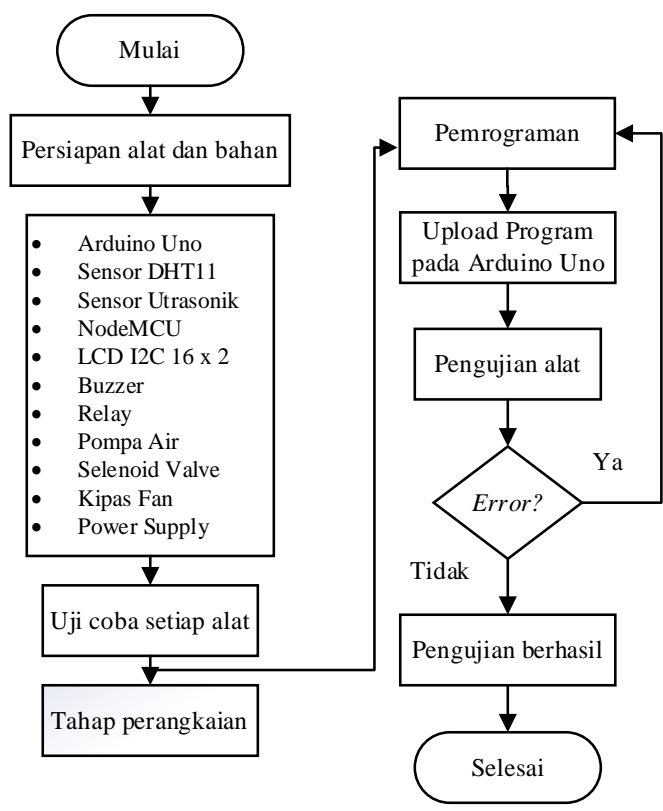

Gambar 5. Diagram Alir Perancangan Alat Keseluruhan

\section{Pengujian Sensor Ultrasonik Dengan LCD I2C 16 × 2}

Pengujian dilakukan untuk mengetahui keakuratan sensor ultrasonik yang akan digunakan dengan cara mengkalibrasi dan membandingan nilai jarak pada penggaris $30 \mathrm{~cm}$ dengan sensor yang diberi objek penghalang di depannya. Nilai yang terbaca oleh sensor akan ditampilkan pada serial monitor Arduino IDE dan LCD $16 \times 2$. Berikut adalah pengujian sensor ultrasonik HC-SR04.

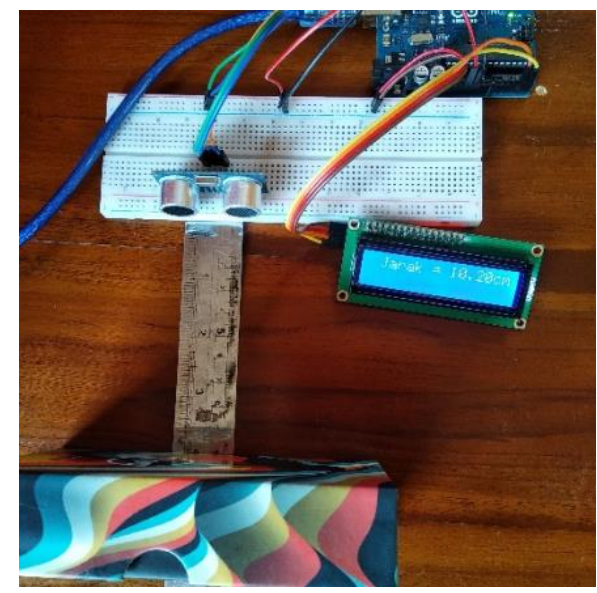

Gambar 6. Pengujian Sensor Ultrasonik Dan LCD 
Berikut adalah data hasil pengujian sensor ultrasonik dengan membandingkan jarak pada penggaris.

Tabel 3, Data Hasil Perbandingan Jarak Sensor Ultrasonik Oleh Penggaris

\begin{tabular}{|c|c|c|c|c|c|c|}
\hline No. & $\begin{array}{c}\text { Pengaris } \\
(\mathbf{c m})\end{array}$ & $\begin{array}{c}\text { Percobaan } \\
\mathbf{1} \\
\text { Sensor } \\
\text { Ultrasonik } \\
(\mathbf{c m})\end{array}$ & $\begin{array}{c}\text { Percobaan } \\
\mathbf{2} \\
\text { Sensor } \\
\text { Ultrasonik } \\
(\mathbf{c m})\end{array}$ & $\begin{array}{c}\text { Percobaan } \\
\mathbf{3} \\
\text { Sensor } \\
\text { Ultrasonik } \\
(\mathbf{c m})\end{array}$ & Selisih & $\begin{array}{c}\text { Error } \\
(\%)\end{array}$ \\
\hline 1 & 5 & 5 & 5 & 5 & 0 & $0 \%$ \\
\hline 2 & 7 & 7 & 7 & 7 & 0 & $0 \%$ \\
\hline 3 & 10 & 10 & 10 & 10 & 0 & $0 \%$ \\
\hline 4 & 13 & 13 & 13 & 13 & 0 & $0 \%$ \\
\hline 5 & 15 & 14 & 15 & 15 & 1 & $0.06 \%$ \\
\hline 6 & 17 & 17 & 17 & 17 & 0 & $0 \%$ \\
\hline 7 & 20 & 20 & 20 & 20 & 0 & $0 \%$ \\
\hline 8 & 23 & 23 & 23 & 23 & 0 & $0 \%$ \\
\hline 9 & 25 & 24 & 25 & 25 & 1 & $0.04 \%$ \\
\hline 10 & 30 & 29 & 30 & 30 & 1 & $0.03 \%$ \\
\hline & \multicolumn{7}{|c|}{ Total error } \\
\hline & \multicolumn{7}{|c|}{ Error rata-rata } & \\
\hline
\end{tabular}

Analisa hasil pengujian sensor ultrasonik:

Data pada Tabel 3 diketahui nilai error rata-rata pada pengujian sensor ultrasonik dan dibandingkan dengan penggaris sebesar $0.013 \%$. Dari hasil pengukuran dan pengujian sensor didapatkan akurasi data pengujian yaitu $0,98 \%$.

\section{Pengujian Sensor Suhu Dan Kelembaban DHT11}

Pengujian dilakukan untuk mengetahui keakuratan sensor yang akan digunakan dengan cara mengkalibrasi dan membandingan nilai suhu kelembaban pada sensor dengan alat hygrometer. Nilai yang terbaca oleh sensor akan ditampilkan pada serial monitor pada serial monitor Arduino IDE dan LCD I2C $16 \times 2$. Berikut adalah gambar pengujian sensor.

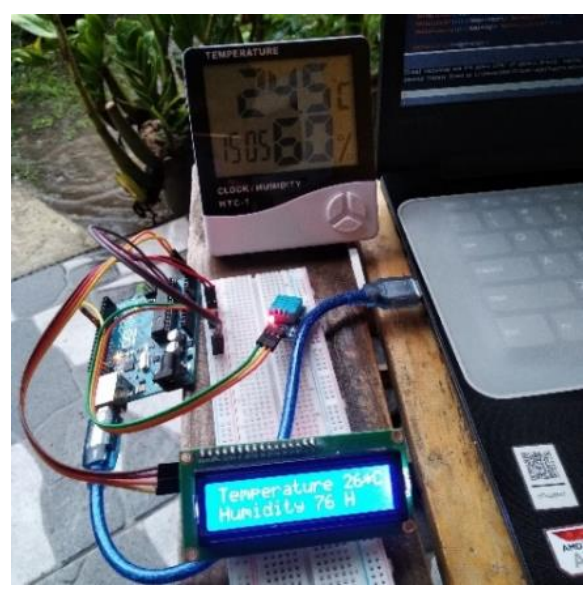

Gambar 7. Pengujian Sensor DHT11 Dan LCD

Berikut adalah data hasil pengujian sensor DHT11 dan LCD dengan membandingkan nilai suhu dan kelembaban dengan alat Hygrometer. 
Tabel 4, Data Hasil Perbandingan Sensor

DHT11 Oleh Hygrometer

\begin{tabular}{|c|c|c|c|c|c|c|c|c|}
\hline \multirow[b]{2}{*}{ Kondisi } & \multicolumn{2}{|c|}{ Hygrometer } & \multicolumn{2}{|c|}{ Sensor DHT11 } & \multicolumn{2}{|c|}{ Selisih } & \multicolumn{2}{|c|}{ Error } \\
\hline & Suhu & $\begin{array}{c}\text { Kelemb } \\
\text { aban }\end{array}$ & Suhu & $\begin{array}{c}\text { Kelemb } \\
\text { aban }\end{array}$ & Suhu & $\begin{array}{c}\text { Kelemb } \\
\text { aban }\end{array}$ & Suhu & $\begin{array}{c}\text { Kelemb } \\
\text { aban }\end{array}$ \\
\hline $\begin{array}{l}\text { Didalam } \\
\text { ruangan }\end{array}$ & $25^{\circ} \mathrm{C}$ & $52 \%$ & $28^{\circ} \mathrm{C}$ & $71 \%$ & 3 & 19 & $0.10 \%$ & $0.26 \%$ \\
\hline $\begin{array}{l}\text { Diluar } \\
\text { ruangan }\end{array}$ & $27^{\circ} \mathrm{C}$ & $48 \%$ & $31^{\circ} \mathrm{C}$ & $66 \%$ & 4 & 18 & $0.12 \%$ & $0.27 \%$ \\
\hline $\begin{array}{l}\text { Sinar } \\
\text { matahari }\end{array}$ & $33^{\circ} \mathrm{C}$ & $33 \%$ & $34^{\circ} \mathrm{C}$ & $63 \%$ & 1 & 30 & $0.02 \%$ & $0.47 \%$ \\
\hline $\begin{array}{l}\text { Panas } \\
\text { hairdryer }\end{array}$ & $43^{\circ} \mathrm{C}$ & $26 \%$ & $48^{\circ} \mathrm{C}$ & $45 \%$ & 5 & 19 & $0.10 \%$ & $0.42 \%$ \\
\hline $\begin{array}{l}\text { Cuaca } \\
\text { hujan deras }\end{array}$ & $23^{\circ} \mathrm{C}$ & $69 \%$ & $24^{\circ} \mathrm{C}$ & $86 \%$ & 1 & 17 & $0.04 \%$ & $0.19 \%$ \\
\hline \multicolumn{7}{|c|}{ Total error } & $0.38 \%$ & $1.61 \%$ \\
\hline \multicolumn{7}{|c|}{ Error rata-rata } & $0.07 \%$ & $0.32 \%$ \\
\hline
\end{tabular}

Analisa hasil pengujian sensor DHT11:

Data pada Tabel 4 diketahui nilai error rata-rata pada pengujian sensor DHT11 dan dibandingkan dengan Hygrometer sebesar $0.07 \%$ error suhu dan $0.32 \%$ error kelembaban. Dari hasil pengukuran dan pengujian sensor didapatkan akurasi data pengujian yaitu $0.93 \%$ suhu dan $0.68 \%$ kelembaban.

\section{Pengujian Aplikasi Blynk}

Dalam pengujian ini pada aplikasi blynk perlu dihubungkan ke jaringan internet (hotspot) dari smartphone dikoneksikan ke NodeMCU yang terprogram. Pada aplikasi blynk ditampilkan Button Controllers sebagai pengendali untuk menghidupkan dan mematikan LED. Berikut adalah tabel data hasil pengujian blynk terhadap LED sebagai output dengan cara menggunakan logika 0 dan 1 yaitu menghidupkan dan mematikan pada lampu LED:

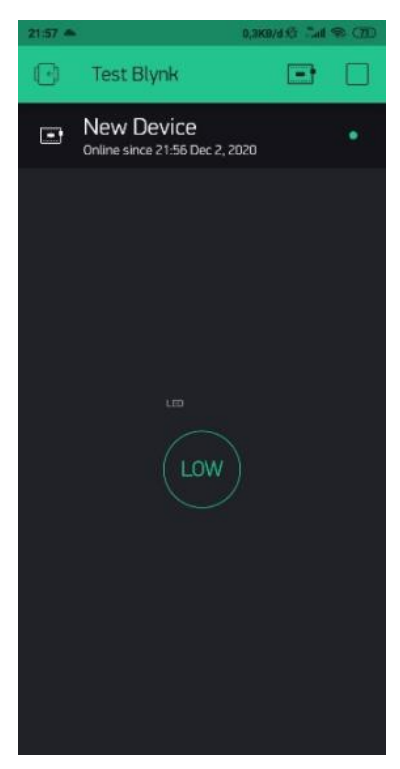

Gambar 8. Tampilan Push Button Blynk 


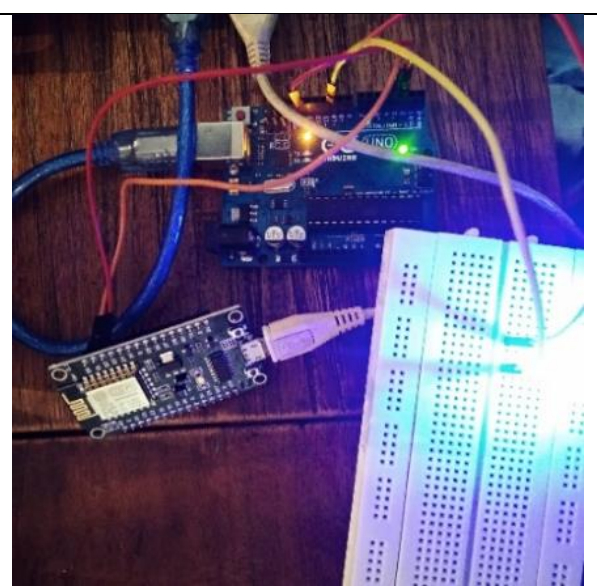

Gambar 9. Pengujian Blynk Mengendalikan LED

Tabel 5, Hasil Pengujian Aplikasi Blynk

\begin{tabular}{|c|c|c|c|}
\hline No & Nilai & Button Blynk & Kondisi LED \\
\hline 1 & 0 & LOW & Mati \\
\hline 2 & 1 & HIGH & Menyala \\
\hline 3 & 0 & LOW & Mati \\
\hline 4 & 1 & HIGH & Menyala \\
\hline 5 & 0 & LOW & Mati \\
\hline 6 & 1 & HIGH & Menyala \\
\hline 7 & 0 & LOW & Mati \\
\hline 8 & 1 & HIGH & Menyala \\
\hline
\end{tabular}

Pada Tabel 5 menjelaskan jika LED dikendalikan oleh NodeMCU dari aplikasi blynk dengan memberikan nilai logika 0 dan 1. Pada saat button blynk ditekan HIGH menghasilkan nilai 1 pada serial monitor maka menyebabkan LED menyala, jika pada saat button blynk ditekan LOW menghasilkan nilai 0 menyebabkan LED tidak menyala.

\section{Data Hasil Uji Alat Keseluruhan}

Berikut adalah tabel data hasil uji alat keseluruhan pada sistem Smart Farming Aeroponik tanaman selada romaine. 
Tabel 6, Data Hasil Uji Kontrol Otomatis

\begin{tabular}{|c|c|c|c|}
\hline No. & Kondisi & Respon Alat & $\begin{array}{c}\text { Waktu Respon } \\
\text { Rangkaian Sistem }\end{array}$ \\
\hline 1 & $\begin{array}{c}\text { Air pada box }<4 \\
\mathrm{~cm}\end{array}$ & $\begin{array}{c}\text { Selenoid valve dan Buzzer } \\
\text { menyala }\end{array}$ & 1 Detik \\
\hline 2 & $\begin{array}{l}\text { Air pada box > } \\
12 \mathrm{~cm}\end{array}$ & $\begin{array}{c}\text { Selenoid valve dan Buzzer } \\
\text { mati }\end{array}$ & - \\
\hline 3 & Suhu udara $>29^{\circ} \mathrm{C}$ & Kipas menyala & 1Detik \\
\hline 4 & Suhu udara $<26^{\circ} \mathrm{C}$ & Kipas mati & $\cdot$ \\
\hline 5 & $\begin{array}{c}\text { Kelembaban udara } \\
<65 \%\end{array}$ & Pompa air menyala & 2 Detik \\
\hline 6 & $\begin{array}{c}\text { Kelembaban udara } \\
>75 \%\end{array}$ & Pompa air mati & - \\
\hline 7 & Air pada box habis & $\begin{array}{c}\text { Selenoid valve dan Buzzer } \\
\text { menyala }\end{array}$ & 1 Detik \\
\hline 8 & Air pada box terisi & $\begin{array}{c}\text { Selenoid valve dan Buzzer } \\
\text { mati }\end{array}$ & \\
\hline 9 & Suhu udara $>29^{\circ} \mathrm{C}$ & Kipas menyala & 1 Detik \\
\hline 10 & Suhu udara $<26^{\circ} \mathrm{C}$ & Kipas mati & $\cdot$ \\
\hline 11 & $\begin{array}{c}\text { Kelembaban udara } \\
<65 \%\end{array}$ & Pompa air menyala & 2 Detik \\
\hline 12 & $\begin{array}{c}\text { Kelembaban udara } \\
>75 \%\end{array}$ & Pompa air mati & - \\
\hline
\end{tabular}

Tabel 6 adalah data kecepatan respon tiap-tiap beban keluaran dengan hasil akurasi delay yang sama, delay waktu ini diakibatkan oleh kelambatan beban untuk berfungsi normal sejak menerima tegangan dari relay karena perbedaan arus oleh pompa, kipas dan solenoid valve.

Tabel 7, Data Hasil Uji Kontrol Jarak Jauh

\begin{tabular}{|c|c|c|c|c|}
\hline No. & Kondisi & Button & Respon Alat & $\begin{array}{c}\text { Waktu Respon } \\
\text { Alat Dari } \\
\text { Blynk }\end{array}$ \\
\hline 1 & \multirow{2}{*}{$\begin{array}{l}\text { Air pada box } \\
\text { range } 4 \mathrm{~cm} \text { - } \\
12 \mathrm{~cm}\end{array}$} & $\begin{array}{l}\text { Widget } \\
\text { Button } 1 \\
(\mathrm{ON})\end{array}$ & $\begin{array}{l}\text { Selenoid valve } \\
\text { menyala }\end{array}$ & 2 Detik \\
\hline 2 & & $\begin{array}{c}\text { Widget } \\
\text { Button 1 } \\
(\mathrm{OFF})\end{array}$ & Selenoid valve mati & 2 Detik \\
\hline 3 & \multirow{2}{*}{$\begin{array}{c}\text { Suhu udara } \\
\text { range } 26^{\circ} \mathrm{C} \text { - } \\
29^{\circ} \mathrm{C}\end{array}$} & $\begin{array}{c}\text { Widget } \\
\text { Button } 2 \\
(\mathrm{ON})\end{array}$ & Kipas menyala & 1 Detik \\
\hline 4 & & $\begin{array}{l}\text { Widget } \\
\text { Button } 2 \\
(\mathrm{OFF}) \\
\end{array}$ & Kipas mati & 3 Detik \\
\hline 5 & \multirow{2}{*}{$\begin{array}{l}\text { Kelembaban } \\
\text { udara range } \\
65 \%-75 \%\end{array}$} & $\begin{array}{c}\text { Widget } \\
\text { Button } 3 \\
(\mathrm{ON})\end{array}$ & $\begin{array}{c}\text { Pompa air \& } \\
\text { Sprayer menyala }\end{array}$ & 2 Detik \\
\hline 6 & & $\begin{array}{l}\text { Widget } \\
\text { Button } 3 \\
\text { (OFF) }\end{array}$ & $\begin{array}{l}\text { Pompa air \& } \\
\text { Sprayer mati }\end{array}$ & 3 Detik \\
\hline 7 & $\begin{array}{c}\text { Air pada box } \\
<4 \mathrm{~cm} / \\
>12 \mathrm{~cm}\end{array}$ & $\begin{array}{c}\text { Widget } \\
\text { Button } 1 \\
(\mathrm{ON} \& \mathrm{OFF})\end{array}$ & Tidak Respon & - \\
\hline 8 & $\begin{array}{c}\text { Suhu udara } \\
<26^{\circ} \mathrm{C} / \\
>29^{\circ} \mathrm{C}\end{array}$ & $\begin{array}{c}\text { Widget } \\
\text { Button } 2 \\
(\mathrm{ON} / \mathrm{OFF})\end{array}$ & Tidak Respon & - \\
\hline 9 & $\begin{array}{c}\text { Kelembaban } \\
\text { udara }<65 \% \text { I } \\
>75 \%\end{array}$ & $\begin{array}{l}\text { Widget } \\
\text { Button } 3 \\
(\mathrm{ON} / \mathrm{OFF})\end{array}$ & Tidak Respon & - \\
\hline
\end{tabular}

Tabel 7 adalah data kecepatan respon tiap-tiap beban keluaran relay dengan hasil akurasi delay yang berbeda, delay waktu respon terhadap tiap-tiap beban ini diakibatkan oleh sinyal wifi (hotspot) yang diterima NodeMCU tidak stabil untuk menerima dan mengirim data ke Arduino Uno.

Write some words of tile ...

(c) 2021 INFOTRON: Jurnal IImiah Teknik Informatika, Elektronika dan Kontrol (Scientific Journal of Informatics, Electronics and Control Engineering). Copyrights. All rights reserved. 


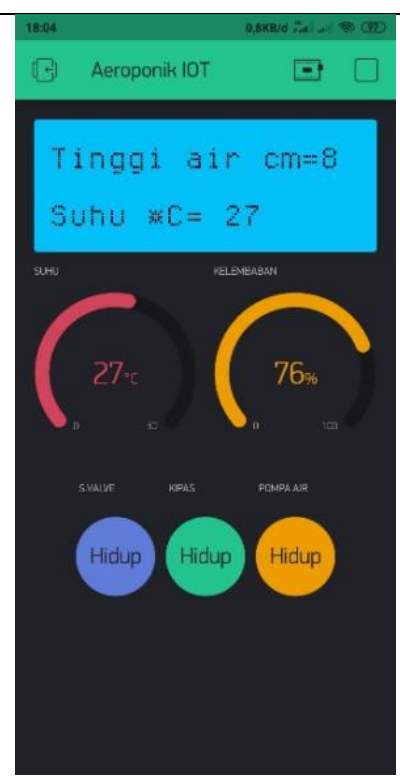

Gambar 10. Tampilan Kontrol Dan Monitoring Smart Farming Pada Blynk

\section{Pengujian Tanaman Selada (Romaine)}

Pada pengujian tanaman selada ini menggunakan dua metode penanaman yaitu metode penanaman pada Smart Farming Aeroponik dan metode penanaman biasa atau konvensional menggunakan media tanah organik (polybag). Pengujiian ini dilakukan secara langsung pada masing-masing metode dengan cara mengukur rata-rata tinnai dan lebar pada tanaman menggunakan meteran. Hasil yang didapat pada $\mathrm{p} \quad$ "esuai dengan waktu saat mengukur pertumbuhan tanaman selada dalam wakty

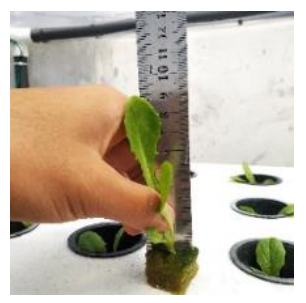

(a)

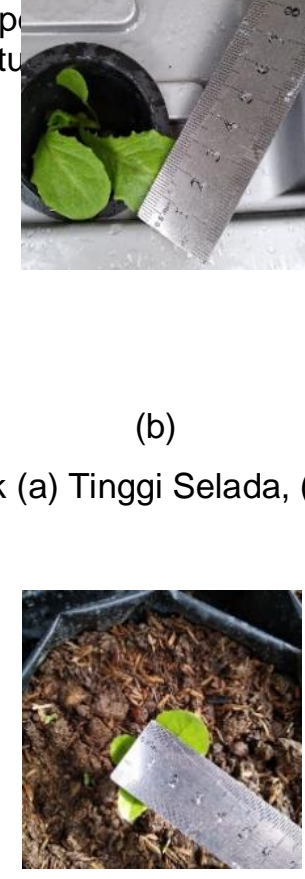

(b)

(a)

Gambar 12. Pengujian Selada Polybag (a) Tinggi Selada, (b) Lebar

Berikut data tabel hasil pengujian pada tanaman selada: 
Tabel 8, Data Hasil Uji Selada

\begin{tabular}{|c|c|c|c|c|c|}
\hline \multirow{2}{*}{ No. } & $\begin{array}{c}\text { Waktu } \\
\text { Pengujian }\end{array}$ & \multicolumn{2}{|c|}{$\begin{array}{c}\text { Metode Smart Farming } \\
\text { Aeroponik }\end{array}$} & \multicolumn{2}{|c|}{$\begin{array}{c}\text { Metode Media Tanah } \\
\text { Organik (Polybag) }\end{array}$} \\
\cline { 2 - 6 } & HST & RTT (cm) & RLD (cm) & RTT (cm) & RLD (cm) \\
\hline 1 & 3 & 6,7 & 1,8 & 5,6 & 1,5 \\
\hline 2 & 6 & 7,4 & 2,2 & 6 & 1,7 \\
\hline 3 & 9 & 8 & 2,6 & 6,4 & 2 \\
\hline 4 & 12 & 8,6 & 2,9 & 6,9 & 2,4 \\
\hline 5 & 15 & 9,5 & 3,4 & 7,5 & 2,8 \\
\hline 6 & 18 & 10,3 & 3,7 & 7,9 & 3,4 \\
\hline 7 & 21 & 11,2 & 4 & 8,4 & 3,9 \\
\hline 8 & 24 & 12 & 4,3 & 9 & 4,3 \\
\hline 9 & 27 & 12,8 & 4,8 & 9,5 & 4,7 \\
\hline 10 & 30 & 13,7 & 5,2 & 10,2 & 5,3 \\
\hline \multicolumn{2}{|c|}{ Nilai rata-rata } & 10,02 & 3,49 & 8,04 & 3,2 \\
\hline
\end{tabular}

HST = hari setelah tanam

$\mathrm{RTT}=$ rata-rata tinggi tanaman

$\mathrm{RLD}=$ rata-rata lebar daun

Data hasil pengujian yang terdapat pada tabel 8 merupakan data perbedaan dari perlakuan tanaman selada yaitu dengan cara disemprot akar di dalam box dengan air yang terkandung nutrisi pada metode aeroponik dan disiram/gembor air biasa pada metode media tanah (Polybag). Data hasil uji pada tabel 8 terdapat perbedaan pertumbuhan selada Aeroponik lebih cepat sedangkan selada pada Polibag sedikit terlambat pertumbuhannya.

\section{Kesimpulan}

Berdasarkan hasil pengujian dan analisa perancangan alat yang telah dilakukan, maka dapat diambil kesimpulan sebagai berikut:

1. Desain sistem Aeroponik Vertical Farming ini didesain dengan bentuk bertingkat yang menggunakan rangka sebagai penompang box dan menambahkan greenhouse sebagai pelindung tanaman dari serangan hama dan melindungi dari cuaca buruk. Hasil rancangan alat dapat diterapkan untuk berbagai jenis sayuran dan dapat diterapkan diberbagai tempat, hanya saja menyesuaikan kondisi berapa keperluan nilai suhu dan kelembaban tanaman yang dibutuhkan dan disesuaikan pada pemrograman mikrokontroler.

2. Monitoring dan pengendali otomatis jarak jauh yang dapat mendeteksi kondisi suhu $26^{\circ} \mathrm{C}$ hingga $29^{\circ} \mathrm{C}$ sedangan kelembaban $75 \%$ hingga $65 \%$, mendeteksi ketinggian air nutrisi didalam box Aeroponik jarak antara $18 \mathrm{~cm}$ hingga $25 \mathrm{~cm}$, dapat melakukan penyiraman tanaman otomatis, dan menaikkan suhu didalam greenhouse yang dikendalikan oleh Arduino UNO R3 dan NodeMCU.

3. Hasil dari pengujian pada sensor ultrasonik dapat mendeteksi jarak $5 \mathrm{~cm}-30 \mathrm{~cm}$ dengan Error ratarata $0.013 \%$ dan jumlah total akurasi data $99.9 \%$, sedangkan pada sensor DHT11 dapat mendeteksi suhu dengan Error rata-rata $0.07 \%$ dan kelembaban dengan Error rata-rata $0.32 \%$. Dari hasil pengukuran dan pengujian sensor didapatkan akurasi data pengujian yaitu $99.9 \%$ suhu dan $99.6 \%$ kelembaban. Nilai rata-rata tumbuh selada (romaine) pada media Smart Farming Aeroponik sebesar 10,02 (RTT) dan 3,49 (RLD), sedangkan nilai rata-rata tumbuh selada pada media Polybag sebesar 8,04 (RTT) dan 3,2 (RLD).

\section{Saran}

1. Saran untuk pengembangan alat Smart Farming Tanaman Selada (Romaine) Dengan Sistem Aeroponik Berbasis IOT yaitu sebagai berikut:

2. Menambahkan input pengendali dengan kondisi jarak lebih jauh untuk mengirim dan menerima data dari perangkat HP ke mikrokontroler bisa berbentuk email atau telegram.

Write some words of tile...

(c) 2021 INFOTRON: Jurnal IImiah Teknik Informatika, Elektronika dan Kontrol (Scientific Journal of Informatics, Electronics and

Control Engineering). Copyrights. All rights reserved. 
3. Menggunakan 2 buah kipas DC dengan ukuran arus yang lebih besar maka kipas berputar lebih kencang yang akan menghasilkan suhu udara yang lebih maksimal sehingga membantu menurunkan suhu udara panas lebih cepat.

4. Menggunakan pompa air yang bertekanan tinggi agar hasil keluaran air dari sprayer lebih halus dan merata.

5. Dapat menambahkan perangkat sumber daya listrik yang hemat energi.

6. Lebih memperhatikan pemberian nutrisi pada tanaman agar tidak tumbuh tinggi dan kurus.

7. Bisa menggunakan jenis sayuran lainnya untuk mengetahui perbandingan pertumbuhan tanaman pada rancangan ini dengan media lainnya.

\section{Refrensi}

[1] Muhammad Widodo dkk, 2015, sistem aeroponik secara otomatis untuk budidaya beberapa sayuran

[2] Ayub Subandi, 2016, rancang bangun sistem aeroponik secara otomatis berbasis mikrokontroler

[3] Martha Vira Sariayu dkk, 2017, pengendali suhu dan kelembaban pada tanaman selada (lactuca sativa I) dengan sistem aeroponik berbasis Arduino Uno R3

[4] Alimuddin dkk, 2018, sistem monitoring parameter suhu cabe merah dengan sistem aeroponik pada greenhouse untuk mendukung ketahanan pangan nasional

[5] Sistem aeroponik untuk budidaya tanaman sayur (Online). (https://8villages.com/full/petani/article/id/5c47e2949b48d7ca64e5aff3) diakses 14 April 2020 